hazards due to accumulation of offal and other wastes. Some processors were not involved in above programme and buried their wastes but complained that they do not have enough area for waste disposal.It is concluded that poultry processing involve with proper waste disposal methods. However, abattoirs use very unhygienic methods for waste disposal while no attention was focused on water pollution as well. Therefore, it is utmost important to educate the abattoirs for proper waste and water management techniques in order to minimize the environmental hazards.

\title{
052 \\ Colour removal and its mechanisms in textile wastewater treatment by UASB reactor system with anaerobic granular sludge
}

\author{
W Somasiri, Li Xiufen, Wenquan Ruan and Jian Chen \\ Laboratory of Environmental Biotechnology, School of Biotechnology, Southern Yangtze University, Wuxi, \\ Jiangsu, PR China.
}

Textile wastewaters generated from different stages of textile processing contain various toxicants or pollutants that are seriously harmful to natural aquatic environment when released without proper treatment. Although there are different methods, which can be adopted for the treatment of textile wastewater, biological approaches are considered as environmentally friendly, low cost and effective methods over other physico-chemical methods. In the present study, simulated textile wastewater (STW) prepared by mixing of three popular acid dyes (Acid blue 204, Acid red 131 and Acid yellow 79) in synthetic wastewater was studied for the decolourization and removal of degradable organic in the laboratory scale Upflow Anaerobic Sludge Blanket Reactor system with anaerobic granular sludge for about five months at different organic and dye loading rates. The colour removal mechanisms under inaerobic treatment were also examined since microbial colour removal occurs basically in two ways namely biological degradation, which is more important in textile wastewater treatment, and adsorption of dye molecules onto microbial biomass. Chemical oxygen demand (COD) removal of acid red 131 (AR 131) containing STW was about $80 \%$ at $300 \mathrm{mg} / \mathrm{l}$ dye concentration and it was over $89 \%$ in acid yellow 79 (AY79) dye containing STW under studied conditions. Although acid blue 204 (AB204) showed a little inhibition over methanogenic consortia, about $93 \%$ of COD removal was observed at $100 \mathrm{mg} / \mathrm{l}$ dye concentration. Colour removal of AR 131 dye containing STW was $95 \%$ and it was credited to biodegradation. Treatment of STW prepared using AY79 showed $95 \%$ colour removal owing to biodegradation while $\mathrm{AB} 204$ was quite resistant to biodegradation by anaerobic microorganisms. Observed colour removal was merely due to the adsorption of dyes onto microbial granules. Even though a little accumulation of volatile fatty acid (VFA) was observed in increased dye concentrations, the detected values of VFA, alkalinity and $\mathrm{pH}$ showed that those values were in the range of desirable limits of anaerobic process. It seems that AR13l and AY79 can be decolourized almost completely by UASB reactor system while AB204 cannot be decolourised since all colour removal attributed to adsorption of dye onto microbial granules. It can be concluded that anaerobic technology can be used for the treatment of textile wastewater containing different dyes as an alternative method over other methods. However, further study of UASB reactor for the treatment of real textile wastewater is suggested to find out matrix effect of other chemicals present in real textile wastewater before application to the real world situations.

\section{3}

\author{
Status of heavy metal pollution in the Lunawa lagoon \\ W R M N K Wickramasinghe ${ }^{1}$, P N Dayawansa ${ }^{1}$ and M D P de Costa ${ }^{2}$ \\ 'Department of Zoology, University of Colombo, Sri Lanka. \\ 2Department of Chemistry, University of Colombo, Sri Lanka.
}

Distribution of five types of heavy metals in the Lunawa Lagoon (Colombo District) was investigated from April to June 2006. Water and bottom sludge samples were obtained at fortnight intervals from nine sampling stations of the lagoon including three drains (Northern, Eastern and Uyana). Water samples were preserved by adding Conc. $\mathrm{HNO}_{3}$ (Analytical Grade) to adjust the $\mathrm{pH}$ to $<2$ and bottom sludge samples were treated by 'Wet Ashing Method' before analysis. Concentrations of $\mathrm{Cu}$,

Proceedings of the International Forestry and Envtronment Symposium 2006 of the

Deparment of Forestry and Environmental srience, University of Sri Jayewardenepura, Sri Lanka 
$\mathrm{Zn}, \mathrm{Pb}, \mathrm{Cd}$ and $\mathrm{Cr}$ were determined by Atomic Absorption Spectrophotometry. $\mathrm{Cu}, \mathrm{Zn}, \mathrm{Pb}$ and $\mathrm{Cr}$ were found both in water and bottom sludge samples of all sites, while $\mathrm{Cd}$ was not recorded from any of the sites. Significantly higher concentrations of heavy metals (Mean \pm SEM: $\mathrm{Cu} 120.75 \mu \mathrm{g} / \mathrm{g} \pm$ 8.43; $\mathrm{Zn} 570.98 \mu \mathrm{g} / \mathrm{g} \pm 11.53 ; \mathrm{Pb} 204.37 \mu \mathrm{g} / \mathrm{g} \pm 7.50 ; \mathrm{Cr} 52.50 \mu \mathrm{g} / \mathrm{g} \pm 4.36$ : One-way ANOVA; $\mathrm{P}<0.01$ ) were found in bottom sludge of the Southern lagoon than the Northern lagoon and the three drains. This is possible because the Southern lagoon is situated away from the sea outfall and the intensity of flushing by sea water is relatively less in this sector. Heavy metal concentrations in water in different sites did not differ significantly, however, water in the Southern lagoon contained a relatively higher concentrations of $\mathrm{Cu}(0.049 \mathrm{ppm} \pm 0.002)$ and $\mathrm{Pb}(0.096 \mathrm{ppm} \pm 0.006)$ while the highest level of $\mathrm{Cr}(0.035 \mathrm{ppm} \pm 0.020)$ and $\mathrm{Zn}(0.151 \mathrm{ppm} \pm 0.017)$ were recorded from the Eastern Drain. Bottom sludge contained significantly higher concentrations of all heavy metals than in water $(\mathrm{P}<0.001)$ indicating accumulation of metal ions in the sludge for a long period of time. Lagoon water could have been contaminated by point sources (such as Automotive Workshops and Textile Factories) and nonpoint sources (such as Service Stations along the Galle Road) of heavy metal pollutants.

\title{
$\underline{054}$ \\ Effects of some water quality parameters and some metals on osmoregulation of Oreochromis mossambicus in Bolgoda lake
}

\author{
K W M Irodanie and A G D H Senevitathne \\ Department of Zoology, University of Sri Jayewardenepura, Sri Lanka.
}

The present study was carried out in Bolgoda Lake at Attidiya, Borupona and Dampe from September 2005 to January 2006 with the objective of studying the effect of some water quality \& some heavy metals on Osmoregulation of Oreochromis mossambicus. Only the Dissolved Oxygen and Transparency showed significant difference among measured water quality parameter within 3 sites. The highest value of Dissolved Oxygen $(9.40 \pm 1.56 \mathrm{mg} / \mathrm{l})$ was recorded at Attidiya \& lowest from Borupona $(3.88 \pm 1.1 \mathrm{mg} / \mathrm{l})$. Dissolved Oxygen of Dampe was $6.44 \pm 2.20 \mathrm{mg} / \mathrm{l}$. Osmoregulatory Capacity of three sites were significantly different. Maximum Osmoregulatory Capacity (240.90 \pm 2.01 ) was recorded in Borupona and minimum Osmoregulatory Capacity $(126.30 \pm 1.12)$ was recorded in Dampe station. Osmoregulatory Capacity of Attidiya was $168.70 \pm 0.79$. A significant negative correlation of Dissolved Oxygen was recorded with Osmoregulatory Capacity. Transparency also made great effect to the Osmoregulatory Capacity. Maximum Osmoregulatory Capacity value was recorded in Borupona that has high transparency $(87 \pm 1.1 \mathrm{~cm})$ and with low Transparency $(65 \pm$ $0.71 \mathrm{~cm})$ minimum Osmoregulatory Capacity value was recorded. That was in Dampe station. Transparency of Attidiya was $80 \pm 0.79 \mathrm{~cm}$.

There was a significant difference $(\mathrm{P}<0.05)$ in the metal levels in a particular organs (gills, muscles) and between the three sites. Gills recorded highest values for all measured metals in three sites. Most abundant metal in three sites was Fe. The Highest value was recorded in Attidiya ( $2940 \pm 27.3 \mu \mathrm{g} / \mathrm{g}$ ). The loweșt Fe value was recorded in Borupona $(1290 \pm 31.5 \mu \mathrm{g} / \mathrm{g})$. Next most abundant metal was $\mathrm{Zn}$. The highest value of $\mathrm{Zn}(805 \pm 7.43 \mu \mathrm{g} / \mathrm{g})$ was recorded in Dampe and lowest value was recorded in Borupona $(382 \pm 3.59 \mu \mathrm{g} / \mathrm{g})$. Cu was found only in Attidiya site, but it was very low, relative to the other elements. A significant negative correlation with Osmoregulatory Capacity was observed for $\mathrm{Zn}$ in gills \& muscles. 